\title{
Vibrational Properties of Benzoxaboroles and Their Interactions with Candida albicans' LeuRS
}

\author{
Ewa Kaczorowska ${ }^{1}$, Agnieszka Adamczyk-Woźniak ${ }^{1, * \mathbb{D}}$, Grażyna Zofia Żukowska ${ }^{1}$ (D), Paulina Kostecka ${ }^{1}$ \\ and Andrzej Sporzyński ${ }^{2, *}$ \\ 1 Faculty of Chemistry, Warsaw University of Technology, ul. Noakowskiego 3, 00-664 Warsaw, Poland; \\ ewak@ch.pw.edu.pl (E.K.); zosia@ch.pw.edu.pl (G.Z.Ż.); paulina.kostecka.stud@pw.edu.pl (P.K.) \\ 2 Faculty of Agriculture and Forestry, University of Warmia and Mazury, Oczapowskiego 8, \\ 10-719 Olsztyn, Poland \\ * Correspondence: agnieszka@ch.pw.edu.pl (A.A.-W.); andrzej.sporzynski@uwm.edu.pl (A.S.)
}

\section{check for}

updates

Citation: Kaczorowska, E.; Adamczyk-Woźniak, A.; Żukowska, G.Z.; Kostecka, P.; Sporzyński, A. Vibrational Properties of Benzoxaboroles and Their Interactions with Candida albicans' LeuRS. Symmetry 2021, 13, 1845. https://doi.org/10.3390/ sym13101845

Academic Editors: Takashiro Akitsu and György Keglevich

Received: 30 June 2021

Accepted: 26 September 2021

Published: 2 October 2021

Publisher's Note: MDPI stays neutral with regard to jurisdictional claims in published maps and institutional affiliations.

Copyright: (c) 2021 by the authors. Licensee MDPI, Basel, Switzerland. This article is an open access article distributed under the terms and conditions of the Creative Commons Attribution (CC BY) license (https:// creativecommons.org/licenses/by/ $4.0 /)$.

\begin{abstract}
Benzoxaboroles have emerged over the past decade mainly due to their growing medicinal importance. Regarding the wide application of IR spectroscopy in the pharmaceutical industry, the vibrational properties of over a dozen of benzoxaboroles were described, based on results of DFT calculations as well as IR and Raman spectra measurements. Investigated series of compounds included the currently available antifungal drug (Tavaborole, AN2690) as well as its derivatives. An intense and well-isolated band corresponding to the $\mathrm{B}-\mathrm{OH}$ group stretching vibrations was present in all experimental IR spectra in the range of $1446-1414 \mathrm{~cm}^{-1}$ and can be considered as characteristic for benzoxaboroles. The vibrational properties of benzoxaboroles are shown to be affected by the formation of intramolecular as well as intermolecular hydrogen bonds, which should also influence the interactions of benzoxaboroles with biomolecules and impact on their biological functions. Docking studies of the benzoxaboroles' adenosine monophosphate (AMP) spiroboronates into the Candida albicans leucyl-RS synthetase binding pocket showed that the introduction of an amine substituent has a strong influence on their binding. The determined values of inhibition constants manifest high potential of some of the investigated molecules as possible inhibitors of that enzyme.
\end{abstract}

Keywords: benzoxaborole; docking; IR spectroscopy; Raman spectroscopy; edenosine monophosphate; antifungal; Candida albicans; enzyme inhibition

\section{Introduction}

Benzoxaboroles have recently gained widespread interest due to their unique properties and high potential as medicinal agents [1-16]. One of these exceptional structures is the recently developed, novel antifungal agent called Tavaborole (Kerydin, AN2690, Figure 1). Tavaborole is a small-molecule drug approved in 2014 by the American Food and Drug Administration (FDA) for the treatment of onychomycosis [2,17-20]. This was shortly followed by FDA approval of Crisaborole (Eucrisa, AN2728) for the treatment of eczema in 2016 [3,4]. Currently, clinical trials of the application of Acoziborole (SCYX-7158) as a single-dose oral treatment of Human African Trypanosomiasis are just about to end [3]. The discovery of the antimicrobial properties of benzoxaboroles was accompanied by their broad structural studies; for instance, the molecular and crystal structure of several benzoxaboroles have been determined in the solid state by X-Ray studies [21-37]. At the same time, application of vibrational spectroscopy in structural studies of benzoxaboroles is rather scarce $[27,38,39]$. Regarding the wide application of IR spectroscopy in the pharmaceutical industry $[40,41]$, the vibrational analysis of benzoxaboroles is the subject of the current study. 
<smiles>OB1OCc2ccccc21</smiles><smiles></smiles>
$2(X=O), 3(X=S), 4\left(X=C_{2}\right)$<smiles>O=Cc1cccc2c1B(O)OC2N1CCN(P)CC1</smiles><smiles>OB1OCc2cc(F)ccc21</smiles>

AN2690

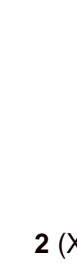<smiles>POB1OC(N2CCN(P)CC2)c2ccccc21</smiles>

$5(\mathrm{R}=\mathrm{Me}), 6(\mathrm{R}=\mathrm{Ph})$, 7 ( $\mathrm{R}=2$ - $\mathrm{F}-\mathrm{Ph}), 8(\mathrm{R}=4-\mathrm{F}-\mathrm{Ph})$

Figure 1. Structures of AN2690 and investigated compounds (1-15).

Among the fungal infections called mycoses, C. albicans remains the most common pathogen, especially for the immune-compromised patients [42-46]. However, there is a limited number of antifungal agents available for therapy [47]. It is worth noting that the postulated mode of antifungal action of AN2690 is via the formation of a spiroboronate with adenosine monophosphate (AMP), built into the editing site of leucyl-tRNA synthetase of Candida albicans [48]. On the basis of the assumed mechanism of Tavaborole's action called the OBORT mechanism (oxaborole tRNA trapping), a reliable model for docking studies was developed and described in our recent paper [49]. It was shown that the docking procedure of the AN2690-AMP spiroboronate results in a structure analogous to that known from crystallographic studies and that the elaborated model can be used for evaluation of other possible boronate ligand bindings [49,50]. Although several molecules combining benzoxaborole and heterocyclic amine structural motives have displayed promising antifungal activity $[21,22,51]$, no interactions of those molecules with Leucyl-RS have been previously studied. In the current study, the recently developed docking procedure was applied to the investigation of intermolecular interactions of unsubstituted benzoxaborole (1), as well as over a dozen 3-aminobenzoxaboroles (2-15, Figure 1) with the enzyme.

\section{Materials and Methods}

\subsection{Structure Optimization, Vibrational Properties and Preparations of Ligand Structures}

Molecular structures of investigated benzoxaboroles (1-15) were optimized in Gaussian03 [52] (b3lyp, [53] 6-311g(2d,p) [54-61] opt freq.). For compounds 1, 5, 10 and 14, the command opt freq = Raman was used. Since compounds 2-15 are chiral molecules, both enantiomers ( $R$ and $S$ ) were taken into account. In the cases of ligands $\mathbf{6}-\mathbf{9}$, the positions of the atoms have were taken from crystal structures and compared to those obtained in the gas phase. The optimized benzoxaborole (1-15) structures were connected to the AMP molecule taken from crystal structure of the AN2690-AMP spiroboronate found in the crystal phase [48] to form the investigated ligands. Two different structural patterns were assumed, varying in arrangement of the benzoxaborole phenyl and the adenosine rings in resulting ligands. Structures denoted with " 1 " represent spiroboronates with those rings at the same side of the spiroboronate, and those denoted with " 2 " represent structures with rings at opposite part of the molecule (Figure 2a,b, respectively). Structures of the 
resulting spiroboronates corresponding to both enantiomers as well as the position of both the benzoxaborole and adenosine rings were not optimized.

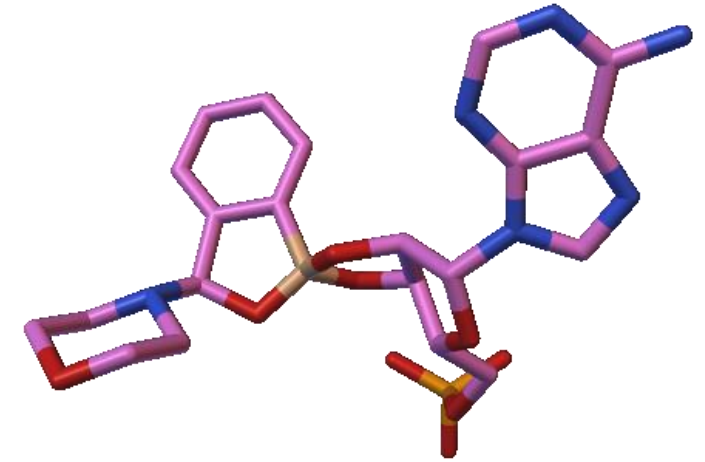

(a)

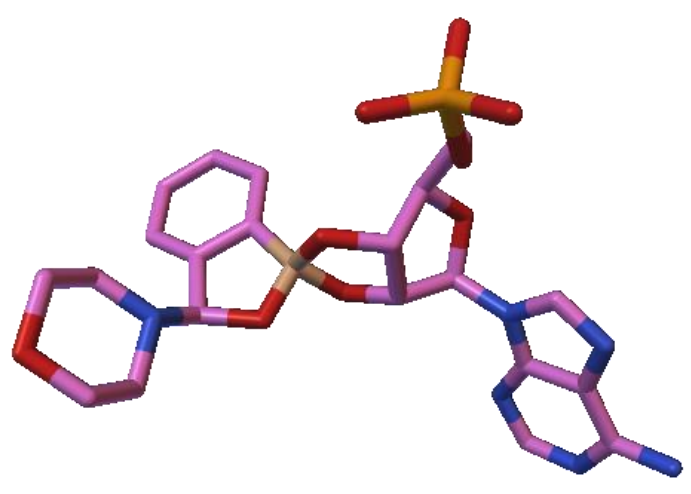

(b)

Figure 2. Examples of structural arrangements for the studied spiroboronates: (a) structure of 2-R-1-AMP with the phenyl benzoxaborole and the adenosine rings at the same side of the molecule; (b) structure of 2-R-2-AMP with the phenyl benzoxaborole and the adenosine rings at opposite sides of the molecule.

\subsection{IR and Raman Spectra Measurements}

Transmission and reflection techniques were used to record infrared spectra. In the case of the transmission technique, the classical method of obtaining a potassium bromide pellet was used. An ATR Golden Gate accessory equipped with a diamond crystal was used in the reflection technique. The spectral resolution was set to $1 \mathrm{~cm}^{-1}$ for the transmission technique and $2 \mathrm{~cm}^{-1}$ for the ATR technique; each spectrum was averaged from 32 scans.

The Raman spectra were collected on a Nicolet Almega Raman dispersive spectrometer. Samples were placed on a glass substrate set on the Peltier cooled Linkam stage. The temperature was stabilized for $10 \mathrm{~min}$ before measurements. The spectra were recorded using a diode laser with a $532 \mathrm{~nm}$ excitation line and a high-resolution grating of 2400 lines $/ \mathrm{mm}$. The exposure time was $15 \mathrm{~s}$ for all experiments; each spectrum was averaged from 2 scans. The obtained spectra were developed by correcting the background and baseline and normalizing the scale.

\subsection{Samples Preparation}

Samples of benzoxaboroles were obtained according to previously reported procedures $[21,25,62]$ and their purity was confirmed on the basis of elemental analysis.

\subsection{Docking Studies}

The crystal structure of editing domain of leucyl-RS synthetase from Candida albicans in complex with AN2690 (structure 5AGJ) was taken from the Protein Databank (www. rcsb.org, accessed on 28 February 2018) and the AN2690-AMP ligand was removed prior to docking studies. The protein structure was processed by AutoDock Tools (http:// autodock.scripps.edu/, accessed on 28 February 2018) to remove water molecules, connect hydrogen atoms and calculate partial charges. The charges were calculated on the basis of standard force-field parameters applied in AutoDock 4.2. Since the standard parameters in AutoDock do not cover the boron atom, the following force-field parameters were introduced: Rii (sum of vdW radii of two atoms of the same type in Angstrom) $=1.98$; epsii $(\mathrm{vdW}$ well depth in $\mathrm{kcal} / \mathrm{mol})=0.034$; vol (atomic solvation volume in Angstrom^3) $=4.6000$; solpar (atomic solvation parameter) $=-0.00110 ;$ Rij_hb (H-bond radius of the heteroatom in contact with a hydrogen in Angstrom) $=0.0$; epsij_hb (well depth of H-bond in $\mathrm{kcal} / \mathrm{mol})=0$; H-bond (integer indicating type of $\mathrm{H}$-bonding atom $(0=$ no $\mathrm{H}$-bond $)=0$; rec_index (initialized to -1 , but later on holds count of how many of this atom type are 
in receptor) $=-1$; bond_index (used in AutoDock to detect bonds; see "mdist.h", enum $\{\mathrm{C}, \mathrm{N}, \mathrm{O}, \mathrm{H}, \mathrm{XX}, \mathrm{P}, \mathrm{S}\})=4[63]$. To judge the binding of the investigated ligands, the Gibbs free energies as well as the resulting inhibition constants of all the ligands were calculated in Autodock [64]. The Gibbs free energies have been determined according to a modified Wesson and Eisenberg method for protein solvation modeling [65]. In the applied method, the binding energy was determined as the difference between the energy of a protein-ligand complex and the sum of the energies of a protein and a ligand [66].

\section{Results}

\subsection{Vibrational Properties of Benzoxaboroles}

Table 1 contains wavenumbers characteristic for the benzoxaboroles' vibrations, the predicted ones based on DFT calculations for $\mathbf{1}$ and its dimer, as well as corresponding signals found in the recorded IR and Raman spectra. A scaling factor of 0.967 was applied for the calculated wavenumbers [67].

Table 1. DFT calculated and experimental IR and Raman frequencies characteristic for the benzoxaboroles' vibrations in 1 and its dimer $\left(\mathrm{cm}^{-1}\right)$.

\begin{tabular}{|c|c|c|c|c|}
\hline No & Vibrations Based on DFT Calculations & 1 & Dimer of 1 & Experimental \\
\hline 1 & $\begin{array}{l}\mathrm{B}-\mathrm{OH} \text { stretching }+ \text { ring stretching } \\
+\mathrm{CH} \text { in plane bending (aromatic) }\end{array}$ & 1460 & 1473 & 1424 (IR) \\
\hline 2 & $\begin{array}{c}\mathrm{B}-\mathrm{OH} \text { stretching } \\
+\mathrm{CH} \text { in plane bending (aromatic) }\end{array}$ & 1402 & 1426 & 1372 (IR) \\
\hline 3 & $\mathrm{~B}-\mathrm{OH}$ in plane bending & 918 & 1208 & 1215 (IR) \\
\hline 4 & BOC out of phase asymmetric stretching & - & 1025 & 1042 (IR) \\
\hline 5 & Ring breathing & 1008 & 1009 & $1020(\mathrm{R})$ \\
\hline 6 & $\mathrm{C}-\mathrm{O}$ stretching $+\mathrm{BO}_{2}$ in plane bending & - & 956 & 976 (IR) \\
\hline 7 & Ring deformation & 815 & 819 & $838(\mathrm{R})$ \\
\hline 8 & $\mathrm{~B}-\mathrm{OH}$ out of plane bending & 523 & 767 & 768 (IR) \\
\hline 9 & $\begin{array}{c}\text { Ring deformation } \\
+ \text { borole ring symmetric stretching }\end{array}$ & 709 & 715 & $\begin{array}{l}721(\mathrm{IR}) \\
723(\mathrm{R})\end{array}$ \\
\hline 10 & $\mathrm{BO}_{2}$ out of plane bending & 633 & 623 & 626 (IR) \\
\hline 11 & $\begin{array}{l}\quad \mathrm{BO}_{2} \text { in plane bending } \\
+ \text { aromatic ring in plane bending }\end{array}$ & 500 & 521 & $524(\mathrm{R})$ \\
\hline
\end{tabular}

IR—experimental IR spectrum, R-experimental Raman spectrum.

Table 2 shows maxima of the most characteristic bands, corresponding to the stretching vibrations of the B-OH as well as C-O groups for AN2690 and remaining investigated benzoxaboroles (1-15) in DFT calculated as well as experimental IR spectra $\left(\mathrm{cm}^{-1}\right)$. In the case of the calculated C-O stretching vibrations, several bands were observed in the corresponding region of the experimental spectra; therefore, no unambiguous assignment was possible and Table 2 contains exclusively DFT calculated data. 
Table 2. Signals corresponding to the B-OH and C-O stretching for AN2690 and remaining investigated benzoxaboroles (1-15) in DFT calculated as well as experimental IR spectra $\left(\mathrm{cm}^{-1}\right)$.

\begin{tabular}{|c|c|c|c|c|c|}
\hline \multirow{2}{*}{$\begin{array}{l}\text { Vibration } \\
\text { method }\end{array}$} & \multicolumn{2}{|c|}{$\begin{array}{l}\text { B-OH Stretching + Ring Stretching } \\
+\mathrm{CH} \text { in Plane Bending (Aromatic) }\end{array}$} & \multicolumn{2}{|c|}{$\begin{array}{c}\text { B-OH Stretching } \\
+\mathrm{CH} \text { in Plane Deformations }\end{array}$} & \multirow{2}{*}{$\begin{array}{c}\begin{array}{c}\text { C-O Stretching } \\
\text { (Borole Ring) }\end{array} \\
\text { DFT }\end{array}$} \\
\hline & DFT & Exp. & DFT & Exp & \\
\hline AN2690 & 1469 & 1418 & 1402 & 1366 & 919 and 1041 \\
\hline 1 & 1460 & 1424 & 1402 & 1371 & 1038 \\
\hline 2 & 1461 & 1413 [39] & 1410 & 1347 [39] & 1024 \\
\hline 3 & 1462 & - & 1410 & 一 & 918 and 1026 \\
\hline 4 & 1461 & - & 1407 & - & 913 \\
\hline 5 & 1460 & 1427 & 1407 & 1352 & 1023 \\
\hline 6 & 1460 & 1414 & 1407 & 1346 & 998 \\
\hline 7 & 1460 & 1414 & 1406 & 1372 & 854 \\
\hline 8 & 1460 & 1429 & 1406 & 1346 [10] & 854 \\
\hline 9 & 1464 & 1414 & 一 & 1332 & 965 \\
\hline 10 & 1464 & 1414 & - & 1349 & 978 \\
\hline 11 & 1469 & - & 1416 & - & 853 \\
\hline 12 & 1469 & - & 1417 & - & 852 \\
\hline 13 & 1469 & 一 & 1413 & - & 932 \\
\hline 14 & 1467 & 1446 & 1416 & 1371 & 1021 \\
\hline 15 & 1468 & 1431 & 1420 & 1377 & 882 \\
\hline
\end{tabular}

C=O stretching for 9: exp.-1685; predicted-1690 and for 10: exp.-1689; predicted-1689, exp. = experimental.

\subsection{Docking Studies of Benzoxaboroles' AMP Spiroesters with C. albicans LeuRS}

Taking all the mentioned structural issues into account (i.e., optical isomerism as well as rings' arrangement in the resulting spiroboronate), 66 different ligands for fifteen investigated compounds (1-15) were prepared. Coordinates of all the input as well as optimized structures are given in Tables S2-S30 (Supplementary Material). The results of the docking experiments for all the ligands are presented in Table S1 (Supplementary Material). Table 3 collects the structures of the lowest energy of binding among all the studied ligands, representing the strongest ligand-enzyme interactions (the lowest inhibition constant). The lowest binding energy, number of structures, mean binding energy, calculated inhibition constant, and number of hydrogen bonds formed with the ligand are included. The values reported previously for the parent drug (AN2690) [49] are given for comparison (Table 1). The name of the ligand describes its structure; the first number reflects the benzoxaborole studies, then the symbol of the optical isomer ( $R$ or $S$, if applicable), and the last number stands for the arrangement of the benzoxaborole and the phenyl ring in the corresponding spiroboronate. Just to give an example, the following symbol, 3-R-1-AMP, stands for an AMP spiroboronate of benzoxaborole 3 of configuration $R$, in which the AMP and benzoxabororole ring are at the same side of the structure. 
Table 3. Results of docking studies of 1-15 spiroboronates of the lowest inhibition constants with Candida albicans LeuRS.

\begin{tabular}{|c|c|c|c|c|c|}
\hline Ligand & $\begin{array}{c}\text { The Lowest } \\
\text { Binding Energy } \\
\text { (kcal/mol) }\end{array}$ & $\begin{array}{l}\text { Number of } \\
\text { Structures }\end{array}$ & $\begin{array}{c}\text { Mean Binding } \\
\text { Energy } \\
(\text { kcal } / \text { mol })\end{array}$ & $\begin{array}{c}\text { Inhibition } \\
\text { Constant (nM) }\end{array}$ & $\begin{array}{c}\text { Number of } \\
\text { Hydrogen Bonds }\end{array}$ \\
\hline AN2690-AMP & -11.89 & 17 & -10.80 & 1.93 & 5 [49] \\
\hline 1-2-AMP * & -11.51 & 17 & -10.60 & 3.63 & 5 \\
\hline 2-S-2-AMP * & -12.02 & 3 & -10.49 & 1.53 & 3 \\
\hline 3-R-1-AMP * & -13.04 & 2 & -12.48 & 0.28 & 3 \\
\hline $4-R-1-\mathrm{AMP} *$ & -12.86 & 4 & -12.29 & 0.38 & 4 \\
\hline 5-R-2-AMP & -12.21 & 13 & -11.16 & 1.12 & 4 \\
\hline 6-R-1-AMP & -12.73 & 20 & -11.93 & 0.47 & 2 \\
\hline 7-R-2-AMP & -12.24 & 27 & -11.65 & 1.07 & 3 \\
\hline 8-R-1-c-AMP & -12.20 & 29 & -11.37 & 1.15 & 3 \\
\hline 9-R-1-AMP & -12.87 & 26 & -12.00 & 0.36 & 3 \\
\hline $10-R-1-\mathrm{AMP} *$ & -12.17 & 1 & -12.17 & 1.21 & 4 \\
\hline 11-R-1-AMP & -11.20 & 11 & -10.67 & 6.15 & 2 \\
\hline 12-R-1-AMP & -11.68 & 19 & -11.08 & 2.76 & 4 \\
\hline 13-R-1-AMP & -11.85 & 24 & -11.25 & 2.05 & 2 \\
\hline 14-R-1-AMP & -11.26 & 12 & -10.52 & 5.57 & 2 \\
\hline $15-R-2-\mathrm{AMP}$ & -12.92 & 18 & -11.71 & 0.34 & 3 \\
\hline
\end{tabular}

* marks structures of an arrangement analogous to that of AN2690 within the enzyme's binding pocket.

\section{Discussion}

\subsection{Vibrational Properties of Benzoxaboroles}

Despite growing interest in benzoxaboroles as pharmaceutical agents, no vibrational properties of those molecules have been investigated in detail so far. Following the results reported previously for phenylboronic acids and the corresponding boroxines [68], the assignment of signals characteristic of benzoxaborole vibrations in IR spectra was carried out. The assignments were confirmed by a comparison of calculated values with experimental IR spectra (ATR as well as in a $\mathrm{KBr}$ pellet) and supported by the analysis of the Raman spectra, which are sensitive to vibrations with high symmetry. Since the formation of a centrosymmetric dimer is a common structural pattern for benzoxaboroles in the solid state, vibrational characteristics of a dimeric structure should be closer to those found in the solid-state samples analyzed by IR. Most of the signals obtained for $\mathbf{1}$ and its dimer are near each other and in close agreement with the experimental spectra. The most characteristic parts of the calculated spectra of $\mathbf{1}$, its dimer, and experimental spectra are shown in Figure 3. According to expectations, for signals corresponding to groups engaged in formation of a hydrogen-bonded dimer, considerable differences in frequencies determined for $\mathbf{1}$ and its dimer can be observed. It accounts for the band corresponding to the B-OH in-plane bending (No. 3, Table 1), which is centered at $918 \mathrm{~cm}^{-1}$ for the monomer and shifts to $1208 \mathrm{~cm}^{-1}$ for the dimer, whereas a signal of $1215 \mathrm{~cm}^{-1}$ is observed in the experimental spectra. A similar shift is observed for the frequency characteristic of the B-OH out-of-plane bending, which is $523 \mathrm{~cm}^{-1}$ for 1 and $767 \mathrm{~cm}^{-1}$ for the corresponding dimer (No. 8, Table 1), and the maximum of the peak in the experimental IR spectrum is at $768 \mathrm{~cm}^{-1}$. The observed trend is similar to that found in spectra of other compounds able to form dimers or more aggregated structures through the use of hydrogen bonds, e.g., carboxylic acids. The blue shift observed for bands attributed to the $\mathrm{C}(\mathrm{O}) \mathrm{OH}$ group bending vibrations is widely considered to be a result of the stiffening of the structure due to the presence of hydrogen bonds [69]. Some spectral features are exclusive characteristics of dimers. For example, the frequency corresponding to the $\mathrm{C}-\mathrm{O}$ stretching and 
$\mathrm{BO}_{2}$ in-plane bending (No. 6, Table 1) at $956 \mathrm{~cm}^{-1}$ was found only for the dimer, which is in agreement with the position of this band observed in the in experimental spectrum, i.e., $976 \mathrm{~cm}^{-1}$. Bands originating from $\mathrm{B}-\mathrm{OH}$ stretching vibrations are less affected by the hydrogen bond formations; the maximum of the most characteristic and intense signal shifts from $1460 \mathrm{~cm}^{-1}$ for 1 to $1473 \mathrm{~cm}^{-1}$ for its dimer. The considerably less intense signal corresponding to the C-O bond stretching shifts from $957 \mathrm{~cm}^{-1}$ for $\mathbf{1}$ to $1038 \mathrm{~cm}^{-1}$ for the dimeric structure. This effect is similar to that described for carboxylic acids and results from a more rigid structure of the dimer due to the hydrogen bond formation [69].

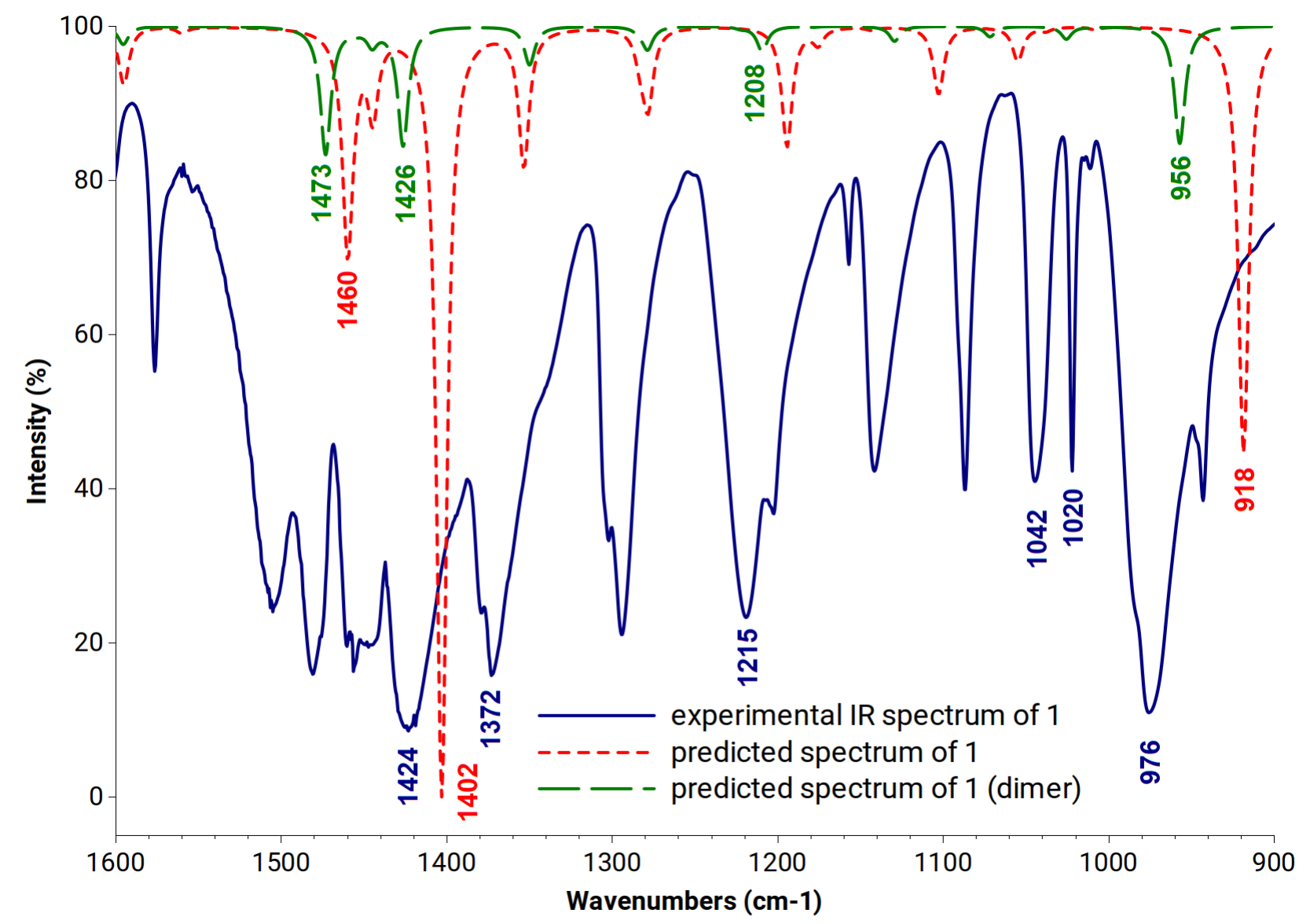

Figure 3. Experimental IR spectrum of a solid sample of $\mathbf{1}$ (blue solid line) together with a DFT predicted spectrum of $\mathbf{1}$ (red dotted line) and dimer of $\mathbf{1}$ (green dotted line). Signals characteristic for the B-O (at about $1400 \mathrm{~cm}^{-1}$ ) as well as the C-O bonds stretching (at about $1000 \mathrm{~cm}^{-1}$ ) are marked with values.

Two characteristic signals, corresponding to $\mathrm{B}-\mathrm{OH}$ stretching vibrations in the remaining investigated benzoxaboroles, were identified on the basis of DFT calculations and are found in the spectral ranges of $1460-1468 \mathrm{~cm}^{-1}$ and $1402-1420 \mathrm{~cm}^{-1}$. The corresponding bands in the experimental IR spectra of the investigated compounds are shifted and occur in the ranges of $1413-1446 \mathrm{~cm}^{-1}$ and $1332-1377 \mathrm{~cm}^{-1}$. One of the possible reasons for this shift is the formation of hydrogen bonds in the investigated solid phase samples of benzoxaboroles. Structures of some of the studied benzoxaboroles in the solid state were previously investigated by a single crystal X-Ray technique, showing dimeric structures for AN2690 [25], 1 [38], 2 [23], 3 [70], 9, [21], hydrogen-bonded infinite chains for 7 [22] and 6 [21], and hydrogen-bonded interactions with the solvent for 8 [22]. It is also in accordance with the shift between calculated bands for $\mathbf{1}$ and its corresponding dimer described above. In the case of the studied formyl derivatives (9 and 10$)$, the $\mathrm{B}-\mathrm{OH}$ group vibration frequencies are affected by the formation of an intramolecular hydrogen bond that engages the B-OH group (Figure 4). Consequently, only one band corresponding to this group 
is observed in DFT calculated spectra at $1464 \mathrm{~cm}^{-1}$ for both compounds (Table 2). The calculated lengths of the intramolecular hydrogen bonds shown in Figure 4 are: $1.869 \AA$ for 9 and $1.870 \AA$ for $\mathbf{1 0}$. They both equal $1.853 \AA$ when applying the dispersion-corrected B3LYP (empirical dispersion = D3BJ) [71].

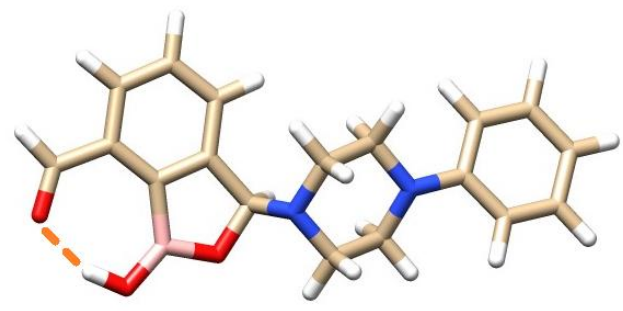

(a)

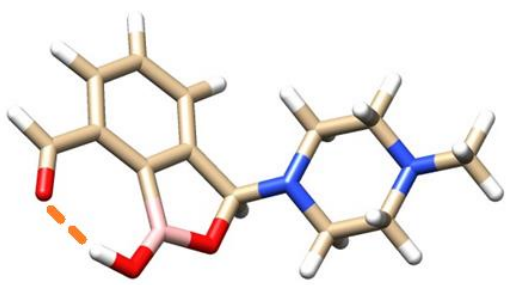

(b)

Figure 4. Intramolecular hydrogen bonds in optimized structures of $\mathbf{9}$ (a) and $\mathbf{1 0}$ (b)—orange dotted lines.

\subsection{Interactions of Benzoxaboroles' AMP Spiroesters with C. albicans LeuRS}

There are several issues to consider when analyzing the results of docking studies. First of all, a large variation in the results of the evaluated inhibition constants is generally observed. The values determined for all the 66 various ligands studied for the investigated benzoxaboroles (1-15) range from $0.28 \mathrm{nM}$ for 3-R-1-AMP to $396.82 \mathrm{nM}$ for 14-S-2-AMP (see Table S1, Supplementary Materials).

When comparing the structures optimized in the gas phase and those taken from crystal structure (Table S1, structures taken from crystal are denoted with " $c$ "), there are no significant differences in the determined inhibition constants in the case of benzoxaboroles 7-9. However, compound 6 exhibits significant differences in the gas-phase optimized structure and that taken from the crystal., The reason for this could be the differences in B-OH group arrangement in benzoxaborole 6, which is anti in the optimized structure (Figure 3a) and syn in the crystal phase [21]. In the cases of structures 7-9, the conformation is identical in both the solid and gas phases, which results in similar inhibition constants determined for both input structures [21,22].

One of the crucial issues to consider is the influence of optical isomerism on interactions with the enzyme. The differences in the determined inhibition constants for optical isomers are significant in most of the studied cases. For example, it is $4.39 \mathrm{nM}$ for 2-R-1-AMP and $53.52 \mathrm{nM}$ for 2-S-1-AMP. At the same time, enantiomer $R$ displays generally lower inhibition constant values (see Table S1). It is worth noting that among the most-interacting ligands presented in Table 3, only one structure is enantiomer $S$ (ligand 2-S-2-AMP), whereas all the remaining structures are enantiomers $R$. These results may denote some chirality of the enzyme's active site [72]. In most cases, both enantiomers in a pair form different numbers of hydrogen bonds; however, in about one-third of them they are exactly the same. Formation of hydrogen bonds between the enzyme and the docked-in ligands is therefore not highly stereospecific. Nevertheless, enantiomers $\mathrm{R}$ generally tend to form more hydrogen bonds with the binding site of the enzyme (it is $44 \%$ and $24 \%$ for $R$ and $S$, respectively). It was, however, impossible to identify any specific interactions that clearly differentiate the enantiomers' binding.

The other factor influencing the inhibition constant is the arrangement of the benzoxaborole and AMP parts in the structure of the resulting spiroester ligand. Two structural patterns, differing in the reciprocal setting of the benzoxaborole and adenosine rings, can be distinguished. Those are denoted with " 1 " (both rings at the same side of the spironoronate) and " 2 " (rings at the opposite side of the spiroboronate). In all but two cases of pairs of type " 1 " and " 2 " spiroboronates, the differences in the determined values of inhibition constant are significant. When analyzing all the results (Table S1), no clear conclusion can be drawn, since in about $50 \%$ cases structures of type " 1 " or " 2 " interact more strongly 
with the enzyme. It is worth noting, however, that the majority of the most-interacting structures (almost 70\%, Table 3) contain rings at the same side of the ligand (type "1"), whereas in the experimental AN2690-AMP complex they are at the opposite sides of the ligand (type " 2 ").

The formation of hydrogen bonds between the ligand and enzyme strengthens their mutual interactions, resulting in lower inhibition constants. While for both the parent drug (AN2690) as well as for $\mathbf{1}$ the number of hydrogen bonds is five, for the studied 3-amino-benzoxaboroles (2-15) it varies from one (nine ligands, $13 \%$ of all structures) to five (five ligands, $7 \%$ of all structures). Most of the docked-in ligands form, however, three hydrogen bonds (24 ligands, $36 \%$ of all structures) and some of them form two hydrogen bonds (16 ligands, $24 \%$ of all structures). It is worth noticing that, similar to the case of the AN2690-AMP ligand, the vast majority of hydrogen bonds with the enzyme are formed by the AMP part of the studied ligands and not by the benzoxaborole fragment.

The results of docking studies show that the introduction of a spatially structured amine substituent considerably influences the interactions between the enzyme and the tested substances. While the unsubstituted benzoxaborole (1), also known as AN2679, reveals a binding mode analogous to that of AN2690 (Figure 5a,b), most of the ligands studied adopt different positions within the enzyme's binding pocket. Only several studied ligands (namely: 1-4, 10 and 12) adopt positions analogous to that known for AN2690AMP (Table S1). However, all but one of them are amongst the most-interacting ligands given in Table 3. It does not apply exclusively to 12-R-1-AMP, which represents another mode of binding with an inhibition constant of 2.76 (Table 3). It is worth noting that some of the studied derivatives display the in silico determined inhibition constants close to that of the parent drug (Tavaborole, AN2690), suggesting their high antifungal potential. However, several structural issues of the studied 3-aminobenzoxaboroles, such as optical isomerism, various possible arrangements of both components of the spiroester ligands, and a variety of adopted binding modes with the enzyme, may lower the real content of the possibly active structure. This may result in moderate in vitro activity of the studied 3 -amino-benzoxaboroles, especially when applied as a racemic mixture. This is in line with results of anti $C$. albicans activity of 2-15 published recently, showing a considerably lower activity of 3-amino-benzoxaboroles in comparison with AN2690 [21].

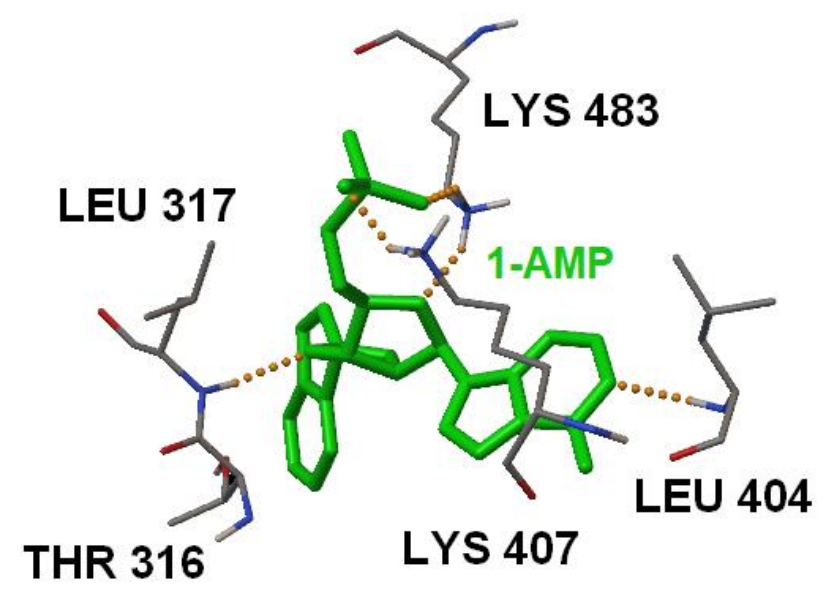

(a)

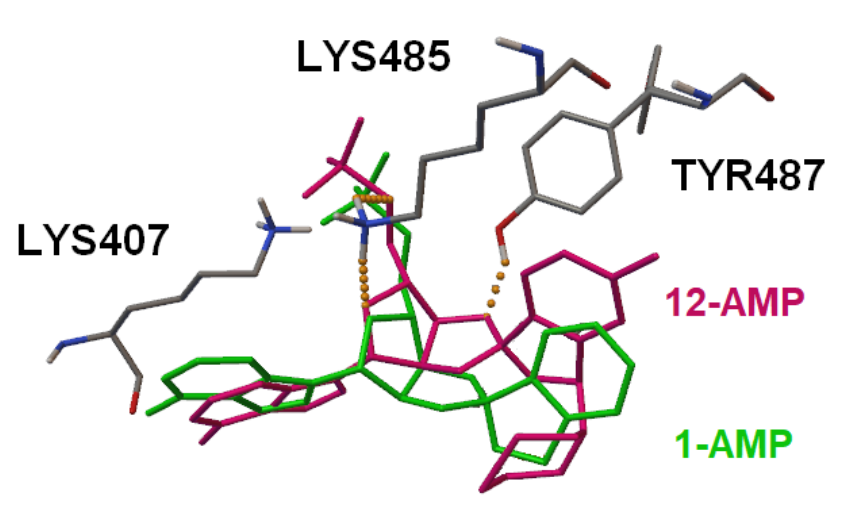

(b)

Figure 5. (a) The structure of 1-AMP spiroboronate docked into C. albicans binding pocket. Orange dotted lines stand for hydrogen bonds; (b) structures of 1-AMP and 12-AMP spiroboronates docked into C. albicans binding pocket. Orange dotted lines stand for hydrogen bonds formed by 12-AMP. 


\section{Conclusions}

Despite considerable differences in the structure of investigated benzoxaboroles, a well-isolated band corresponding to the $\mathrm{B}-\mathrm{OH}$ group stretching vibrations is present in experimental IR spectra of all the studies compounds in the range of $1446-1414 \mathrm{~cm}^{-1}$ and can be considered as characteristic for benzoxaboroles. Several structural issues of the studied possible inhibitors of $C$. albicans LeuRS influence their interaction with the enzyme. The majority of the most-interacting structures are $R$ enantiomers, forming spiroesters with both rings at the same side of the molecule. Some of these spiroesters tend to adopt positions analogous to those of Tavaborole (AN2690), resulting in low inhibition constants and tight interactions with the enzyme. It is worth noting, however, that the majority of the most-interacting ligands adopt a conformation different than that of the parent drug determined in structural studies. Therefore, the strength of their interactions with the enzyme may not be relevant for the function of those compounds as antifungal agents.

Supplementary Materials: The following are available online at https: / www.mdpi.com/article / $10.3390 /$ sym13101845/s1. Results of the docking studies for 66 various spiroester structures (Table S1). Optimized structures of the investigated compounds 2-16 (Figures S1-S29), coordinates of the input and optimal structures of 2-16 (Tables S2-S30). The best structures obtained in the docking studies to Candida albicans leucyl t-RNA synthetase (Figures S30-S96). Coordinates of the best structures obtained in the docking studies to Candida albicans leucyl t-RNA synthetase (Tables S31-S97). Experimental IR and Raman spectra of AN2690, 1, 5-7, 11-15.

Author Contributions: Conceptualization, E.K. and A.A.-W.; methodology, E.K. and G.Z.Ż.; writingoriginal draft preparation, A.A.-W.; writing-review and editing, A.A.-W. and A.S.; visualization, P.K., E.K. and A.A.-W.; funding acquisition, A.A.-W. All authors have read and agreed to the published version of the manuscript.

Funding: This research was funded by National Science Centre, Poland, grant number 2016/23/B/ ST5/02847.

Institutional Review Board Statement: Not applicable.

Informed Consent Statement: Not applicable.

Data Availability Statement: The data presented in this study are available in this paper as well as in Supplementary Material.

Acknowledgments: The support of the Polish National Science Centre (NCN, grant No. 2016/23/B/ ST5/02847) is kindly acknowledged.

Conflicts of Interest: The authors declare no conflict of interest. The funders had no role in the design of the study; in the collection, analyses, or interpretation of data; in the writing of the manuscript, or in the decision to publish the results.

\section{References}

1. Adamczyk-Woźniak, A.; Borys, K.M.; Sporzyński, A. Recent developments in the chemistry and biological applications of benzoxaboroles. Chem. Rev. 2015, 115, 5224-5247. [CrossRef]

2. Fernandes, G.F.S.; Denny, W.A.; Dos Santos, J.L. Boron in drug design: Recent advances in the development of new therapeutic agents. Eur. J. Med. Chem. 2019, 179, 791-804. [CrossRef] [PubMed]

3. Mereddy, G.R.; Chakradhar, A.; Rutkoski, R.M.; Jonnalagadda, S.C. Benzoboroxoles: Synthesis and applications in medicinal chemistry. J. Organomet. Chem. 2018, 865, 12-22. [CrossRef]

4. Nocentini, A.; Supuran, C.T.; Winum, J.-Y. Benzoxaborole compounds for therapeutic uses: A patent review (2010-2018). Expert Opin. Ther. Pat. 2018, 28, 493-504. [CrossRef] [PubMed]

5. Lunde, C.S.; Stebbins, E.E.; Jumani, R.S.; Hasan, M.M.; Miller, P.; Barlow, J.; Freund, Y.R.; Berry, P.; Stefanakis, R.; Gut, J.; et al. Identification of a potent benzoxaborole drug candidate for treating cryptosporidiosis. Nat. Commun. 2019, 10. [CrossRef] [PubMed]

6. Samaniego Lopez, C.; Martínez, J.H.; Acebedo, S.L.; Spagnuolo, C.C. Benzoxaboroles as dynamic covalent receptors for bioconjugation and transport of nucleosides and related drugs: Proof of action in HeLa cells. Bioorganic Chem. 2019. [CrossRef] [PubMed]

7. Lapa, G.B.; Mirchink, E.P.; Isakova, E.B.; Preobrazhenskaya, M.N. Two approaches to the use of benzo[c][1,2]oxaboroles as active fragments for synthetic transformation of clarithromycin *. J. Enzyme Inhib. Med. Chem. 2017, 32, 452-456. [CrossRef] 
8. Yang, F.; Zhu, M.; Zhang, J.; Zhou, H. Synthesis of biologically active boron-containing compounds. MedChemComm 2018, 9, 201-211. [CrossRef]

9. Nocentini, A.; Cadoni, R.; Del Prete, S.; Capasso, C.; Dumy, P.; Gratteri, P.; Supuran, C.T.; Winum, J.-Y.Y. Benzoxaboroles as Efficient Inhibitors of the $\beta$-carbonic anhydrases from pathogenic fungi: Activity and modeling study. ACS Med. Chem. Lett. 2017, 8, 1194-1198. [CrossRef]

10. Si, Y.; Basak, S.; Li, Y.; Merino, J.; Iuliano, J.; Walker, S.; Tonge, P. antibacterial activity and mode of action of a sulfonamide-based class of oxaborole leucyl-tRNA-synthetase inhibitors. ACS Infect. Dis. 2019, 5, 1231-1238. [CrossRef]

11. Zhang, J.; Yang, F.; Qiao, Z.; Zhu, M.; Zhou, H. Chalcone-benzoxaborole hybrids as novel anticancer agents. Bioorgainc Med. Chem. Lett. 2016, 26, 5797-5801. [CrossRef]

12. Tevyashova, A.N.; Korolev, A.M.; Mirchink, E.P.; Isakova, E.B.; Osterman, I.A. Synthesis and evaluation of biological activity of benzoxaborole derivatives of azithromycin. J. Antibiot. 2019, 72, 22-33. [CrossRef] [PubMed]

13. Alterio, V.; Cadoni, R.; Esposito, D.; Vullo, D.; Di Fiore, A.; Monti, S.M.; Caporale, A.; Ruvo, M.; Sechi, M.; Dumy, P.; et al. Benzoxaborole as a new chemotype for carbonic anhydrase inhibition. Chem. Commun. 2016, 52, 11983-11986. [CrossRef] [PubMed]

14. Zhang, Y.-K.K.; Plattner, J.; Easom, E.; Jacobs, R.; Guo, D.; Freund, Y.; Berry, P.; Ciaravino, V.; Erve, J.; Rosenthal, P.; et al. Benzoxaborole antimalarial agents. Part 5. Lead optimization of novel amide pyrazinyloxy benzoxaboroles and identification of a preclinical candidate. J. Med. Chem. 2017, 60, 5889-5908. [CrossRef] [PubMed]

15. Liu, C.T.; Tomsho, J.W.; Benkovic, S.J. The unique chemistry of benzoxaboroles: Current and emerging applications in biotechnology and therapeutic treatments. Bioorg. Med. Chem. 2014, 22, 4462-4473. [CrossRef]

16. Xiao, Y.-C.; Chen, X.-P.; Deng, J.; Yan, Y.-H.; Zhu, K.-R.; Li, G.; Yu, J.-L.; Brem, J.; Chen, F.; Schofield, C.J.; et al. Design and enantioselective synthesis of 3-( $\alpha$-acrylic acid) benzoxaboroles to combat carbapenemase resistance. Chem. Commun. 2021, 57, 7709-7712. [CrossRef]

17. Lipner, S.R.; Scher, R.K. Onychomycosis: Treatment and prevention of recurrence. J. Am. Acad. Dermatol. 2019, 80, 853-867. [CrossRef]

18. Elewski, B.; Pariser, D.; Rich, P.; Scher, R.K. Current and emerging options in the treatment of onychomycosis. Semin. Cutan. Med. Surg. 2013, 32, S9-S12. [CrossRef]

19. Kubota-Ishida, N.; Takei-Masuda, N.; Kaneda, K.; Nagira, Y.; Chikada, T.; Nomoto, M.; Tabata, Y.; Takahata, S.; Maebashi, K.; Hui, X.; et al. In vitro human onychopharmacokinetic and pharmacodynamic analyses of me1111, a new topical agent for onychomycosis. Antimicrob. Agents Chemother. 2018, 62, e00779-17. [CrossRef]

20. Ciaravino, V.; Coronado, D.; Lanphear, C.; Hoberman, A.; Chanda, S. Tavaborole, a novel boron-containing small molecule pharmaceutical agent for topical treatment of onychomycosis: I. reproductive and developmental toxicity studies. Int. J. Toxicol. 2016, 35, 530-542. [CrossRef]

21. Wieczorek, D.; Kaczorowska, E.; Wiśniewska, M.; Madura, I.D.; Leśniak, M.; Lipok, J.; Adamczyk-Woźniak, A. Synthesis and influence of 3-amino benzoxaboroles structure on their activity against Candida albicans. Molecules 2020, 25, 5999. [CrossRef]

22. Borys, K.M.; Matuszewska, A.; Wieczorek, D.; Kopczyńska, K.; Lipok, J.; Madura, I.D.; Adamczyk-Woźniak, A. Synthesis and structural elucidation of novel antifungal $\mathrm{N}$-(fluorophenyl)piperazinyl benzoxaboroles and their analogues. J. Mol. Struct. 2019, 1181, 587-598. [CrossRef]

23. Sporzyński, A.; Lewandowski, M.; Rogowska, P.; Cyrański, M.K. 1,3-Dihydro-1-hydroxy-3-morpholin-4-yl-2,1-benzoxaborole: Product of the reaction of o-formylphenylboronic acid with morpholine. Appl. Organomet. Chem. 2005, 19, 1202-1203. [CrossRef]

24. Adamczyk-Woźniak, A.; Borys, K.M.; Madura, I.D.; Pawełko, A.; Tomecka, E.; Żukowski, K. Lewis acidity and sugar receptor activity of 3-amino-substituted benzoxaboroles and their ortho-aminomethylphenylboronic acid analogues. New J. Chem. 2013, 37, 188-194. [CrossRef]

25. Madura, I.D.; Adamczyk-Woźniak, A.; Jakubczyk, M.; Sporzyński, A. 5-Fluoro-1,3-dihydro-2,1-benzoxaborol-1-ol. Acta Crystallogr. Sect. E Struct. Rep. Online 2011, 67, o414-o415. [CrossRef] [PubMed]

26. Sene, S.; Pizzoccaro, M.A.; Vezzani, J.; Reinholdt, M.; Gaveau, P.; Berthomieu, D.; Bégu, S.; Gervais, C.; Bonhomme, C.; Renaudin, G.; et al. Coordination networks based on boronate and benzoxaborolate ligands. Crystals 2016, 6, 48. [CrossRef]

27. Sene, S.; Berthomieu, D.; Donnadieu, B.; Richeter, S.; Vezzani, J.; Granier, D.; Begu, S.; Mutin, H.; Gervais, C.; Laurencin, D. A combined experimental-computational study of benzoxaborole crystal structures. CrystEngComm 2014, 16, 4999-5011. [CrossRef]

28. Al-Zoubi, R.M.; Al-Zoubi, M.S.; Jaradat, K.T.; McDonald, R. Design, synthesis and X-ray crystal structure of iodinated benzoboroxole derivatives by consecutive metal-iodine exchange of 3,4,5-triiodoanisole. Eur. J. Org. Chem. 2017, 2017, 5800-5808. [CrossRef]

29. Dąbrowski, M.; Kurach, P.; Luliński, S.; Serwatowski, J. An ortho-lithiated derivative of protected phenylboronic acid: An approach to ortho-functionalized arylboronic acids and 1,3-dihydro-1-hydroxybenzo[c][2,1]oxaboroles. Appl. Organomet. Chem. 2007, 21, 234-238. [CrossRef]

30. Hazra, G.; Maity, S.; Bhowmick, S.; Ghorai, P. Organocatalytic, enantioselective synthesis of benzoxaboroles via Wittig/oxaMichael reaction Cascade of alpha-formyl boronic acids. Chem. Sci. 2017, 8, 3026-3030. [CrossRef]

31. Adamczyk-Woźniak, A.; Cabaj, M.K.; Dominiak, P.M.; Gajowiec, P.; Gierczyk, B.; Lipok, J.; Popenda, Ł.; Schroeder, G.; Tomecka, E.; Urbańskia, P.; et al. The influence of fluorine position on the properties of fluorobenzoxaboroles. Bioorg. Chem. 2015, 60, 130-135. [CrossRef] 
32. Adamczyk-Woźniak, A.; Ejsmont, K.; Gierczyk, B.B.; Kaczorowska, E.; Matuszewska, A.; Schroeder, G.; Sporzyński, A.; Zarychta, B. Novel 2,6-disubstituted phenylboronic compounds-Synthesis, crystal structures, solution behaviour and reactivity. J. Organomet. Chem. 2015, 788, 36-41. [CrossRef]

33. Czub, M.; Durka, K.; Luliński, S.; Łosiewicz, J.; Serwatowski, J.; Urban, M.; Woźniak, K. Synthesis and transformations of functionalized benzosiloxaboroles. Eur. J. Org. Chem. 2017, 2017, 818-826. [CrossRef]

34. Yamamoto, Y.; Ishii, J.-I.; Nishiyama, H.; Itoh, K. Cp*RuCl-catalyzed formal intermolecular cyclotrimerization of three unsymmetrical alkynes through a boron temporary tether: Regioselective four-component coupling synthesis of phthalides. J. Am. Chem. Soc. 2005, 127, 9625-9631. [CrossRef]

35. Zhang, H.; Shen, S.; Yang, X.; Sun, X. Synthesis of 3-indolyl-substituted benzoboroxole via friedel-crafts reaction in water. Chin. J. Org. Chem. 2014, 34, 2456-2461. [CrossRef]

36. Gunasekera, D.S.; Gerold, D.J.; Aalderks, N.S.; Chandra, J.S.; Maanu, C.A.; Kiprof, P.; Zhdankin, V.V.; Reddy, M.V.R. Practical synthesis and applications of benzoboroxoles. Tetrahedron 2007, 63, 9401-9405. [CrossRef]

37. Miyamoto, S.; Matsuoka, A.; Yamada, Y.; Ishikawa, R.; Hayashida, O. Benzoxaborole catalyst for site-selective modification of polyols. Eur. J. Org. Chem. 2020, 1598-1602. [CrossRef]

38. Adamczyk-Woźniak, A.; Cyrański, M.K.; Jakubczyk, M.; Klimentowska, P.; Koll, A.; Kołodziejczak, J.; Pojmaj, G.; Żubrowska, A.; Żukowska, G.Z.; Sporzyński, A. Influence of the substituents on the structure and properties of benzoxaboroles. J. Phys. Chem. A 2010, 114, 2324-2330. [CrossRef] [PubMed]

39. Jezierska, A.; Panek, J.J.; Żukowska, G.Z.; Sporzyński, A. A combined experimental and theoretical study of benzoxaborole derivatives by Raman and IR spectroscopy, static DFT, and first-principle molecular dynamics. J. Phys. Org. Chem. 2010, 23, 451-460. [CrossRef]

40. Song, Y.; Cong, Y.; Wang, B.; Zhang, N. Applications of Fourier transform infrared spectroscopy to pharmaceutical preparations. Expert Opin. Drug Deliv. 2020, 17, 551-571. [CrossRef]

41. Bunaciu, A.A.; Aboul-Enein, H.Y.; Fleschin, S. Application of fourier transform infrared spectrophotometry in pharmaceutical drugs analysis. Appl. Spectrosc. Rev. 2010, 45, 206-219. [CrossRef]

42. Turner, S.A.; Butler, G. The Candida pathogenic species complex. Cold Spring Harb. Perspect. Med. 2014, 4, a019778. [CrossRef]

43. Zirkel, J.; Klinker, H.; Kuhn, A.; Abele-Horn, M.; Tappe, D.; Turnwald, D.; Einsele, H.; Heinz, W.J. Epidemiology of Candida blood stream infections in patients with hematological malignancies or solid tumors. Med. Mycol. 2012, 50, 50-55. [CrossRef]

44. Benedict, K.; Jackson, B.R.; Chiller, T.; Beer, K.D. Estimation of direct healthcare costs of fungal diseases in the United States. Clin. Infect. Dis. 2019, 68, 1791-1797. [CrossRef] [PubMed]

45. Pfaller, M.A.; Pappas, P.G.; Wingard, J.R. Invasive fungal pathogens: Current epidemiological trends. Clin. Infect. Dis. 2006, 43, S3-S14. [CrossRef]

46. Pappas, P.G.; Lionakis, M.S.; Arendrup, M.C.; Ostrosky-Zeichner, L.; Kullberg, B.J. Invasive candidiasis. Nat. Rev. Dis. Prim. 2018, 4, 18026. [CrossRef] [PubMed]

47. de Oliveira Santos, G.C.; Vasconcelos, C.C.; Lopes, A.J.O.; do Socorro de Sousa Cartágenes, M.; Filho, A.K.D.B.; do Nascimento, F.R.F.; Ramos, R.M.; Pires, E.R.R.B.; de Andrade, M.S.; Rocha, F.M.G.; et al. Candida Infections and therapeutic strategies: Mechanisms of action for traditional and alternative agents. Front. Microbiol. 2018, 9, 1351. [CrossRef] [PubMed]

48. Rock, F.L.; Mao, W.; Yaremchuk, A.; Tukalo, M.; Crépin, T.; Zhou, H.; Zhang, Y.K.; Hernandez, V.; Akama, T.; Baker, S.J.; et al. An antifungal agent inhibits an aminoacyl-tRNA synthetase by trapping tRNA in the editing site. Science 2007, 316, 1759-1761. [CrossRef]

49. Adamczyk-Woźniak, A.; Gozdalik, J.T.; Wieczorek, D.; Madura, I.D.; Kaczorowska, E.; Brzezińska, E.; Sporzyński, A.; Lipok, J. Synthesis, properties and antimicrobial activity of 5-trifluoromethyl-2-formylphenylboronic acid. Molecules 2020, $25,799$. [CrossRef]

50. Adamczyk-Woźniak, A.; Gozdalik, J.T.; Kaczorowska, E.; Durka, K.; Wieczorek, D.; Zarzeczańska, D.; Sporzyński, A. (Trifluoromethoxy)phenylboronic acids: Structures, properties, and antibacterial activity. Molecules 2021, 26, 2007. [CrossRef]

51. Adamczyk-Woźniak, A.; Komarovska-Porokhnyavets, O.; Misterkiewicz, B.; Novikov, V.P.; Sporzyński, A. Biological activity of selected boronic acids and their derivatives. Appl. Organomet. Chem. 2012, 26, 390-393. [CrossRef]

52. Frisch, M.J.; Trucks, G.W.; Schlegel, H.B.; Scuseria, G.E.; Robb, M.A.; Cheeseman, J.R.; Montgomery, J.A., Jr.; Vreven, T.; Kudin, K.N.; Burant, J.C.; et al. Gaussian 03, Revision C. 02; Gaussian. Inc.: Wallingford, CT, USA, 2004.

53. Lee, C.; Yang, W.; Parr, R.G. Development of the Colle-Salvetti correlation-energy formula into a functional of the electron density. Phys. Rev. B 1988, 37, 785-789. [CrossRef]

54. Wachters, A.J.H. Gaussian basis set for molecular wavefunctions containing third-row atoms. J. Chem. Phys. 1970, 52, 1033-1036. [CrossRef]

55. Hay, P.J. Gaussian basis sets for molecular calculations. The representation of $3 \mathrm{~d}$ orbitals in transition-metal atoms. J. Chem. Phys. 1977, 66, 4377-4384. [CrossRef]

56. Raghavachari, K.; Trucks, G.W. Highly correlated systems. Excitation energies of first row transition metals Sc-Cu. J. Chem. Phys. 1989, 91, 1062-1065. [CrossRef]

57. Binning, R.C., Jr.; Curtiss, L.A. Compact contracted basis sets for third-row atoms: Ga-Kr. J. Comput. Chem. 1990, 11, 1206-1216. [CrossRef] 
58. McGrath, M.P.; Radom, L. Extension of Gaussian-1 (G1) theory to bromine-containing molecules. J. Chem. Phys. 1991, 94, 511-516. [CrossRef]

59. Curtiss, L.A.; McGrath, M.P.; Blaudeau, J.; Davis, N.E.; Binning, R.C.; Radom, L. Extension of Gaussian-2 theory to molecules containing third-row atoms Ga-Kr. J. Chem. Phys. 1995, 103, 6104-6113. [CrossRef]

60. McLean, A.D.; Chandler, G.S. Contracted Gaussian basis sets for molecular calculations. I. Second row atoms, Z = 11-18. J. Chem. Phys. 1980, 72, 5639-5648. [CrossRef]

61. Krishnan, R.; Binkley, J.S.; Seeger, R.; Pople, J.A. Self-consistent molecular orbital methods. XX. A basis set for correlated wave functions. J. Chem. Phys. 1980, 72, 650-654. [CrossRef]

62. Adamczyk-Woźniak, A.; Madura, I.; Pawełko, A.; Sporzyński, A.; Żubrowska, A.; Żyła, J. Amination-reduction reaction as simple protocol for potential boronic molecular receptors. Insight in supramolecular structure directed by weak interactions. Cent. Eur. J. Chem. 2011, 9, 199-205. [CrossRef]

63. Otkidach, D.S.; Pletnev, I. V Conformational analysis of boron-containing compounds using Gillespie-Kepert version of molecular mechanics. J. Mol. Struct. Theochem. 2001, 536, 65-72. [CrossRef]

64. Morris, G.M.; Huey, R.; Lindstrom, W.; Sanner, M.F.; Belew, R.K.; Goodsell, D.S.; Olson, A.J. AutoDock4 and AutoDockTools4: Automated docking with selective receptor flexibility. J. Comput. Chem. 2009, 30, 2785-2791. [CrossRef] [PubMed]

65. Wesson, L.; Eisenberg, D. Atomic solvation parameters applied to molecular dynamics of proteins in solution. Protein Sci. 1992, 1, 227-235. [CrossRef]

66. Morris, G.M.; Goodsell, D.S.; Halliday, R.S.; Huey, R.; Hart, W.E.; Belew, R.K.; Olson, A.J. Automated docking using a Lamarckian genetic algorithm and an empirical binding free energy function. J. Comput. Chem. 1998, 19, 1639-1662. [CrossRef]

67. Scott, A.P.; Radom, L. Harmonic vibrational frequencies: An evaluation of hartree-Fock, Møller-Plesset, quadratic configuration interaction, density functional theory, and semiempirical scale factors. J. Phys. Chem. 1996, 100, 16502-16513. [CrossRef]

68. Smith, M.K.; Northrop, B.H. Vibrational properties of boroxine anhydride and boronate ester materials: Model systems for the diagnostic characterization of covalent organic frameworks. Chem. Mater. 2014, 26, 3781-3795. [CrossRef]

69. Millikan, R.C.; Pitzer, K.S. The infrared spectra of dimeric and crystalline formic acid. J. Am. Chem. Soc. 1958, 80, 3515-3521. [CrossRef]

70. Adamczyk-Woźniak, A.; Madura, I.; Velders, A.H.; Sporzyński, A. Diverse reactivity of 2-formylphenylboronic acid with secondary amines: Synthesis of 3-amino-substituted benzoxaboroles. Tetrahedron Lett. 2010, 51, 6181-6185. [CrossRef]

71. Grimme, S.; Ehrlich, S.; Goerigk, L. Effect of the damping function in dispersion corrected density functional theory. J. Comput. Chem. 2011, 32, 1456-1465. [CrossRef]

72. Cintas, P. Biochirality: Origins, Evolution and Molecular Recognition; Topics in Current Chemistry; Springer: Berlin/Heidelberg, Germany, 2014; ISBN 978-3642376269. 